\title{
CHARACTERIZATION OF MORTAR WITH PENNISETUM PURPUREUM ASHES AS CEMENT REPLACEMENT MATERIAL
}

\author{
MOHD HAZiman WAN IBRAHIM ${ }^{1 *}$, MOHAMMEd YAHYA AL-FASIH ${ }^{2}$, \\ NiK NAdia AMIRA NiK PA ${ }^{1}$, RAMAdHANSYAH PUTRA JAYA ${ }^{3}$, \\ AND MUHAMMAD IKHSAN SETIAWAN ${ }^{4}$ \\ ${ }^{1}$ Jamilus Research Center, Faculty of Civil Engineering and Built Environment, \\ Universiti Tun Hussein Onn Malaysia, Parit Raja, Johor, Malaysia \\ ${ }^{2}$ Forensic Engineering Centre (FEC), Institute of Smart Infrastructure and Innovative \\ Construction (ISIIC), School of Civil Engineering, Faculty of Engineering, \\ Universiti Teknologi Malaysia, 81310 Johor Bahru, Johor \\ ${ }^{3}$ Department of Civil Engineering, College of Engineering, Universiti Malaysia Pahang, \\ 26300 Gambang, Pahang, Malaysia. \\ ${ }^{4}$ Department of Civil Engineering, Faculty of Engineering, Narotama University, \\ Surabaya, Jawa, Indonesia \\ *Corresponding author: haziman@uthm.edu.my
}

(Received: 27th August 2020; Accepted: $30^{\text {th }}$ January 2021; Published on-line: $4^{\text {th }}$ July 2021)

\begin{abstract}
In this study, the properties of mortar such as standard consistency, setting time, compressive strength, and water absorption rate were investigated. The cement was replaced with Pennisetum purpureum ashes (PPA) in different particle sizes and dosages. PPA was produced in greyish-white ash with total reactive oxides ranging from $37 \%$ to $41.1 \%$. Pennisetum purpureum grass (PPG) was burned with a controlled process at 350 ${ }^{\circ} \mathrm{C}$ for the first 3 hours and $600{ }^{\circ} \mathrm{C}$ for another 3 hours at a heating rate of $10{ }^{\circ} \mathrm{C} / \mathrm{min}$. Then, PPG was ground in three different grinding durations (1,3, and 6 hours) producing ashes with particle sizes of $10.58 \mu \mathrm{m}, 10.25 \mu \mathrm{m}$, and $9.30 \mu \mathrm{m}$, respectively. The physical, chemical, and microstructural properties of PPA were evaluated through several tests; particle size analysis, X-ray diffraction analysis, loss on ignition, and chemical composition. Results indicated that PPA is more suitable for use as filling material as a substitute for cement than pozzolanic material as its reactive oxides are less than $50 \%$. The $15 \% 6 \mathrm{H}-\mathrm{PPA}$ at 28 days was found to be the optimum PPA replacement dosage and grinding time with cement as it achieved the highest strength and lower water absorption rate among all samples at 7 and 28 days.
\end{abstract}

ABSTRAK: Kajian ini berkenaan sifat mortar seperti konsistensi standard, masa penyediaan, kekuatan menyeluruh, dan kadar penyerapan air. Simen ditukar dengan abu Pennisetum purpureum (PPA) dalam saiz partikel dan sukatan berbeza. PPA pula dihasilkan melalui habuk putih-kekelabuan dengan total reaktif oksida dengan julat purata $37 \%$ ke $41.1 \%$. Rumput Pennisetum purpureum (PPG) dibakar dengan proses kawalan pada $350{ }^{\circ} \mathrm{C}$ selama 3 jam pertama dan $600{ }^{\circ} \mathrm{C}$ pada 3 jam berikutnya pada kadar pemanasan $10^{\circ} \mathrm{C} / \mathrm{min}$. Kemudian, PPG dikisar dalam tiga tempoh kisaran berbeza $(1,3$, dan 6 jam) menghasilkan abu dengan saiz partikel $10.58 \mu \mathrm{m}, 10.25 \mu \mathrm{m}$, dan $9.30 \mu \mathrm{m}$, masing-masing. Fizikal, larutan kimia dan sifat struktur mikro PPA telah dikaji melalui pelbagai ujian; analisis saiz partikel, analisis pembelauan X-ray, kehilangan semasa penyalaan dan kandungan kimia. Dapatan kajian menunjukkan PPA adalah lebih sesuai digunakan sebagai material pengisian ganti kepada simen berbanding material pozzolanik kerana reaktif oksida adalah kurang daripada 50\%. PPA adalah maksimum pada $15 \% 6 \mathrm{H}-$ 
PPA selama 28 hari, didapati lebih sesuai sebagai dos pengganti dan masa kisaran bersama simen, kerana kekuatan menyeluruh adalah paling tinggi dan kadar penyerapan air paling kurang antara semua sampel pada 7 dan 28 hari.

KEYWORDS: Pennisetum purpureum ashes; PPA mortar; replacement dosage; grinding time

\section{INTRODUCTION}

The cement industry is one a strategic industry acting as a contributor to several other industries such as real-estate, construction, and infrastructure, where it plays an important role in the world economy [1]. Concrete materials should not only possess good workability, excellent mechanical properties, and durability, but also offer environmental and economic benefits. However, the cement production of the world, which is estimated at around 1.6 billion tons, contributes about $7 \%$ of the global carbon dioxide emissions due to the burning of limestone and clay. Thus, widespread cement usage in the industry has been considered unsustainable. Therefore, an alternative need to be found to help the cement industry, protect the environment, and also to promote sustainable development for the construction industry and the country. The sustainability concept in engineering practice is focused on the development of new materials for construction purposes and environmentally friendly materials.

Recently, the search for alternative binders, natural admixtures, or cement replacement materials has been the subject of many studies. The waste raw materials have been used as cement replacement materials to reduce the carbon footprint and enhance sustainability. The biomass waste ashes that contain a high amount of silica content such as sugar cane bagasse ashes [2], rice husk ashes [3], palm oil fuel ash [4], and corn cob ash [5] can be used as supplementary cementitious materials (SCMs). Biomass is defined as a sustainable energy source with carbon dioxide $\left(\mathrm{CO}_{2}\right)$ neutralization potential. Ghiasvand and Ramezanianpour [1] reported that the energy consumption and carbon dioxide $\left(\mathrm{CO}_{2}\right)$ emissions can be reduced through using SCMs. Furthermore, a portion of cement in a concrete system replaced by SCMs will participate in primary or secondary hydration reactions, increasing the volume fraction of binding phases and decreasing porosity in the microstructure of the concrete.

Other than traditional cementitious materials such as rice husk ash, silica fume, and fly ash, one of the alternatives is the ashes extracted from elephant grass or Napier grass (Pennisetum purpureum). The leaves of elephant grass are currently used as a food source for ruminants, but its trunks are dumped in the landfill. The trunks from the grass could be recycled into silica-based products. Napier grass can be harvested four times a year and it has the potential to produce about 100 barrels of oil equivalent per hectare [6]. Elephant grass is used now in Malaysia as a sustainable resource for the electricity supply system due to its advantages of yield capability, wide propagation, and high dry material [7]. However, a large quantity of elephant grass ashes was generated during the direct burning process of these activities. These ashes will finally be deposited in landfills with the consequent environmental, technical, economic, and social problems [8]. The output energy from Napier grass is estimated as 25 times higher than the input energy consisting of a high amount of lignocellulosic material.

However, elephant grass contains a considerable amount of amorphous silica due to the extraction of ortho-silicic acid from groundwater by the plant and its ashes can be economically attractive to the production of a pozzolan, which is similar to some byproducts used as biomass such as sugar cane bagasse and rice husk [8]. Saruchera et al. [9] 
found that elephant grass was suitable for ash production as all results of chemical composition meet the minimum requirement to be classified as a pozzolan. Nakanishi et al. [10] found that the pozzolanic behavior of elephant grass paste was similar to silica fume paste where the main hydrated phases in $\mathrm{EGC} / \mathrm{Ca}(\mathrm{OH})_{2}$ consisted of $\mathrm{C}-\mathrm{S}-\mathrm{H}$ gels similar to $\mathrm{SF} / \mathrm{Ca}(\mathrm{OH})_{2}$ paste.

Therefore, using Napier grass as an alternate binder resource may protect the environment and enable the building industry to grow sustainably. Several studies have already reported the potential activity of PPA and its effect on the mechanical properties of concrete or mortar. Cordeiro and Sales [8] found that the 28-day compressive strength, Young's Modulus, and water absorption did not change due to the replacement of $20 \%$ of the cement with EGA compared to the reference concrete. Cordeiro and Sales [11] found that the compressive strength increased after 180 days of curing compared to the reference concrete. However, Erika et al. [12] reported that the compressive strength decreased by $12 \%$ due to $20 \%$ cement replacement with EGA.

In the context of pozzolanic ash, Ramadhansyah et al. [13] reported that the use of finer particles of the ash produced better strength and affected the workability, creep, shrinkage, and water-cement ratio properties. As the fineness of the material relies on their grinding times, it was proven that the strength of concrete increased with the increase of the grinding time of the Rice Husk ash until the optimum value is reached [13]. Since the ashes from the pozzolanic material are expected to behave similarly, the grinding time of the PPA might also improve the mechanical properties of the mortar.

Therefore, the objective of this study is to investigate the effects of grinding times and dosages of PPA as a partial replacement for cement on the mechanical properties of the blended-cement pastes. The compressive strength, standard consistency, setting time, and water absorption rate of the cement blended paste were considered. The pozzolanic character of PPA was determined through the particle size analysis, scanning electron microscope (SEM), loss on ignition, and chemical composition.

\section{ORGANIZING EXPERIMENTAL PROGRAM}

\subsection{Materials}

The cement used in this study was Ordinary Portland Cement (OPC) conforming to EN 197-1: 2000 standard [14] and manufactured by Tasek Corporation Berhad (ISO 9001, ISO 14001 and OHSAS 18001 certified company). Physically, the Portland cement particle size of $63 \mu \mathrm{m}$ and the fine aggregates that passed $2.36 \mathrm{~mm}$ sieve were used for cement mortar. Pennisetum purpureum, also known as Napier grass of Taiwan type, was used. The raw materials of $P$. purpureum grass were supplied from Hole Grass Farm Pagoh, Muar, Johor, Malaysia.

\subsection{Pennisetum purpureum Ash (PPA) Production}

The production of PPA included four steps: first, the P. purpureum grass was cut into small pieces, and washed with tap water to remove undesirable residue. Then, the grass was oven-dried at $110{ }^{\circ} \mathrm{C}$ for 24 hours to ensure the grass was completely dried. The oven-dried grass then burned using Lenton Atmospheric control furnace at $350{ }^{\circ} \mathrm{C}$ for the first 3 hours and $600{ }^{\circ} \mathrm{C}$ for another 3 hours to produce final ash with a heating rate of $10{ }^{\circ} \mathrm{C} / \mathrm{min}$. The ash was allowed to cool down inside the furnace. The PPA was sieved and ground in Fritsch ball mill for 1, 3, and 6 hours to produce ash with three different particle size ranges. The production process is shown in Fig. 1 and Fig. 2. 


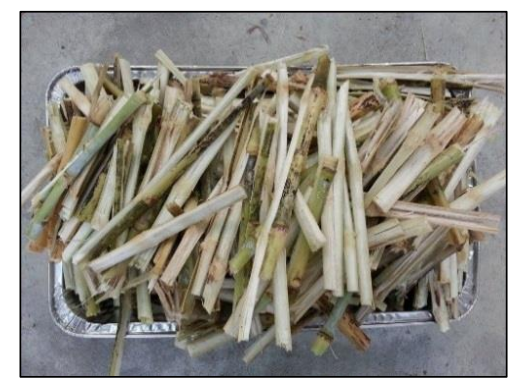

(a) Cut and washed

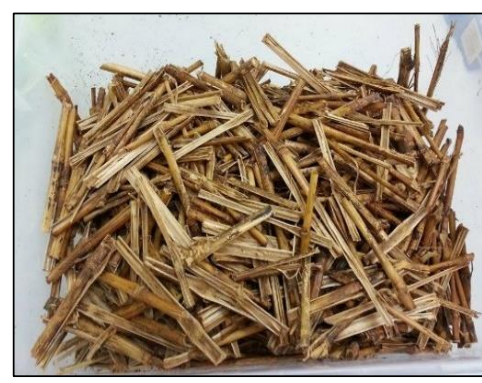

(b) 24 hours' oven-dried at $110{ }^{\circ} \mathrm{C}$

Fig. 1: Pieces of P. purpureum plant.

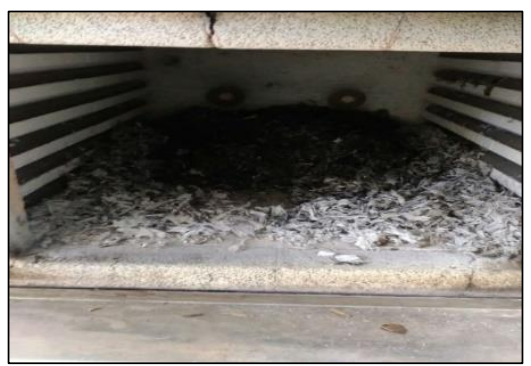

(a) At Lenton Atmospheric control furnace

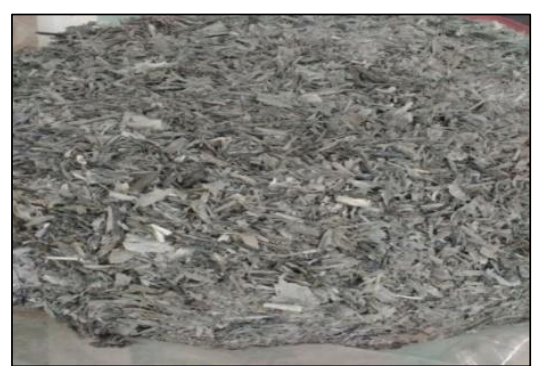

(b) After 6 hours of the burning process

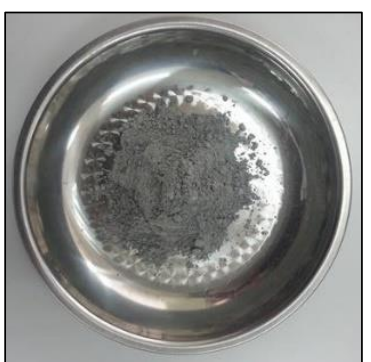

(c) Ground PPA (final ashes)

Fig. 2: Burning process of PPA.

\subsection{Characterizations and Microstructural Analysis of PPA}

The particle size distributions of the PPA and OPC were determined using the laser particle size analyzer (Fritsch Analysette 22) as shown in Table 1. It can be observed that PPA particle size decreased or specific surface area increased with the increase in grinding duration. The average particle size $\left(\mathrm{D}_{50}\right)$ of the PPA was less than the cement particle size $(18 \mu \mathrm{m})$ so that it can be classified as fillers as stated by Abu Bakar et al. [15]. Also, it can participate actively with the mixes through pozzolanic reaction as stated by Venkatanarayanan and Rangaraju [12].

Table 1: Granulometric value for D10, D50, and D90 of materials

\begin{tabular}{cccccc}
\hline Sample & $\begin{array}{c}\text { Grinding } \\
\text { duration } \\
\text { (hours) }\end{array}$ & $\begin{array}{c}\text { Specific surface } \\
\text { area }\left(\mathbf{c m}^{2} / \mathbf{c m}^{\mathbf{3}}\right)\end{array}$ & ${ }^{*} \mathbf{D}_{\mathbf{1 0}}(\boldsymbol{\mu \mathbf { m }})$ & ${ }^{*} \mathbf{D}_{\mathbf{5 0}}(\boldsymbol{\mu \mathbf { m }})$ & ${ }^{*} \mathbf{D}_{\mathbf{9}}(\boldsymbol{\mu \mathbf { m }})$ \\
\hline 1H-PPA & 1 & 10949 & 3.41 & 10.58 & 20.58 \\
3H-PPA & 3 & 11008 & 3.11 & 10.25 & 21.03 \\
6H-PPA & 6 & 12671 & 2.55 & 9.30 & 21.97 \\
OPC & - & 3350 & 1.2 & 18 & 67 \\
\hline
\end{tabular}

$* \mathrm{D}_{10}$ : particle size which lies below $10 \%$ of the material; $\mathrm{D}_{50}$ : particle size which lies below $50 \%$ of the material; $\mathrm{D}_{90}$ : particle size which lies below $90 \%$ of the material.

The chemical composition analysis of raw materials was carried out using X-ray fluorescence (XRF). Table 2 shows that PPA mostly consists of silica, iron, and alumina with small quantities of sulfate, magnesium, and calcium, etc. Despite different grinding durations, there are no significant variations in the chemical composition of the PPA. 
Summations of the percentage of $\mathrm{SiO}_{2}, \mathrm{Al}_{2} \mathrm{O}_{3}$, and $\mathrm{Fe}_{2} \mathrm{O}_{3}$ present in PPA were $37.98 \%$, $37.02 \%$, and $41.15 \%$ for $1 \mathrm{H}-\mathrm{PPA}, 3 \mathrm{H}-\mathrm{PPA}$, and $6 \mathrm{H}-\mathrm{PPA}$, respectively. Thus, the PPA does not achieve a desirable amount of reactive oxides to be classified as Class $\mathrm{F}$ or Class $\mathrm{C}$ pozzolan where the total reactive oxides $\left(\mathrm{SiO}_{2}, \mathrm{Al}_{2} \mathrm{O}_{3}\right.$, and $\left.\mathrm{Fe}_{2} \mathrm{O}_{3}\right)$ must be above $50 \%$ and $70 \%$, respectively.

Table 2: Chemical composition of PPA by weight percent

\begin{tabular}{ccccc}
\hline Oxide & $\begin{array}{c}\text { 1H-PPA } \\
(\text { *wt.\%) }\end{array}$ & $\begin{array}{c}\text { 3H-PPA } \\
(\text { (*wt.\%) }\end{array}$ & $\begin{array}{c}\text { 6H-PPA } \\
(\text { (*wt.\%) }\end{array}$ & $\begin{array}{c}\text { OPC } \\
(\text { (*wt.\%) }\end{array}$ \\
\hline $\mathrm{SiO}_{2}$ & 31.7 & 30.4 & 33.8 & 17.9 \\
$\mathrm{Al}_{2} \mathrm{O}_{3}$ & 4.54 & 4.70 & 5.45 & 4.69 \\
$\mathrm{Fe}_{2} \mathrm{O}_{3}$ & 1.74 & 1.92 & 1.81 & 2.97 \\
$\mathrm{SO}_{3}$ & 5.52 & 5.23 & 4.95 & - \\
$\mathrm{MgO}$ & 0.74 & 0.75 & 0.78 & 1.62 \\
$\mathrm{CaO}$ & 20.8 & 21.0 & 22.2 & - \\
$\mathrm{K}_{2} \mathrm{O}$ & 1.62 & 1.87 & 1.62 & 0.51 \\
$\mathrm{TiO}_{2}$ & 0.25 & 0.23 & 0.27 & - \\
\hline
\end{tabular}

${ }^{*} \mathrm{wt} \%$ means weight percent

The microstructural analysis for PPA was conducted using a JEOL scanning electron microscope (SEM) for all grinding periods as shown in Fig. 3. It was found that the unground PPA (UG-PPA) sample has an irregular shape with many sizes as shown in Fig. 3a. The UG-PPA grains have a porous structure that was quite similar to that found by $[10,11]$. The skeleton of a honeycomb-like particle and vesicular shape in the UG-PPA, whereas the particles are in highly irregular shapes and porous structures as shown in Fig. 3b. After being ground as shown in Fig. 3 c, d, and e, the particle sizes become smaller, which indicates a significant degradation of the PPA structure due to the grinding process. The particle shape of the ground PPA had better dispersion than UG-PPA which proved that the mechanical grinding improved the particle surface and morphology of PPA.

\subsection{Mix Proportions}

Five different percentages of PPA with cement by weight of $0 \%, 5 \%, 10 \%, 15 \%$, and $20 \%$ were prepared. Three different particle sizes of PPA from three different grinding times $(1,3$, and 6 hours) were considered in this study. The cement to sand ratio was 1:2.75 by weight while the water-cement ratio for all samples was 0.485 . The mixed composition of the mortar cube was shown in Table 3. A total of 234 sample cubes was prepared in which 9 samples were prepared for each mixing batch.

\subsection{Testing}

\subsubsection{Loss on Ignition Test}

The loss on ignition is defined as the percent mass loss of a constant weight of a sample as ignited at a high temperature. The loss on ignition test was conducted for both the OPC and PPA as per ASTM C114-07 (Part16) [16]. An empty platinum crucible was weighed and marked as $\mathrm{W}_{1}$. About 1.5 grams of the sample were weighed in the platinum crucible and marked as $\mathrm{W}_{2}$. Then, the platinum crucible was covered and ignited in a muffle furnace at a temperature of $950^{\circ} \mathrm{C} \pm 50^{\circ} \mathrm{C}$ for 15 minutes. The sample was taken out and cooled for 20 minutes, then weighted and marked as $\mathrm{W}_{3}$. The percentage of loss on ignition was calculated to the nearest 0.1 using Eq. 1.

Loss on ignition $(\%)=\left[\left(\mathrm{W}_{2}-\mathrm{W}_{3}\right) /\left(\mathrm{W}_{2}-\mathrm{W}_{1}\right)\right] \times 100 \%$ 


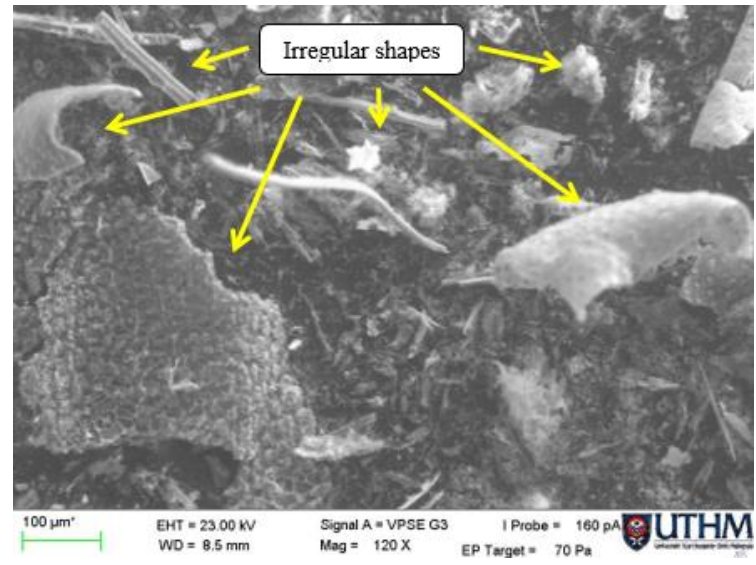

(a) UG -PPA contained irregular shapes

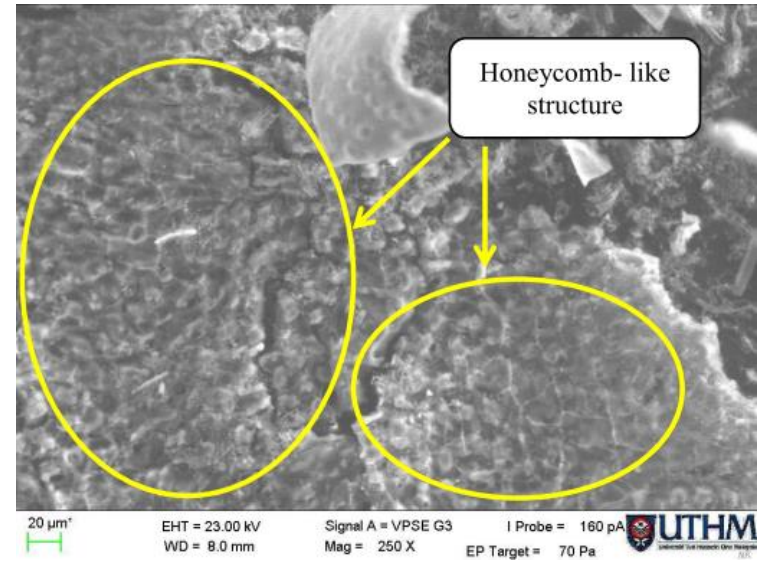

(b) UG-PPA contained a honeycomb-like structure

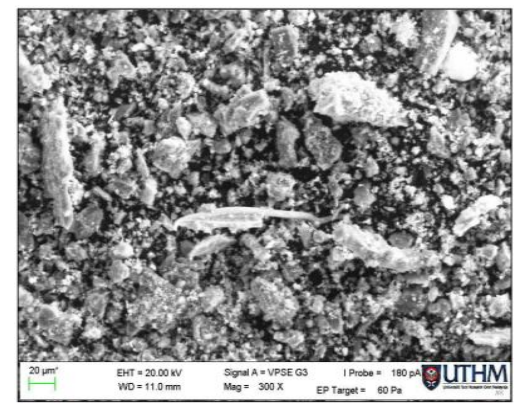

(c) $1 \mathrm{H}-\mathrm{PPA}$

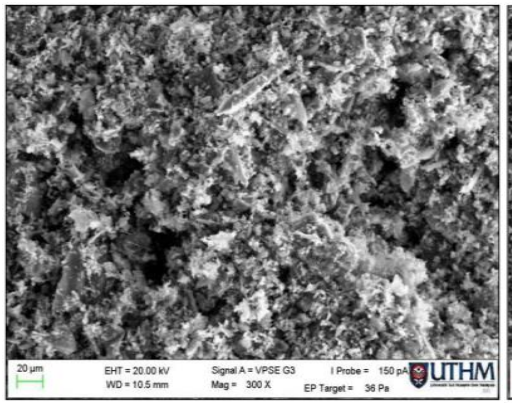

(d) $3 \mathrm{H}-\mathrm{PPA}$

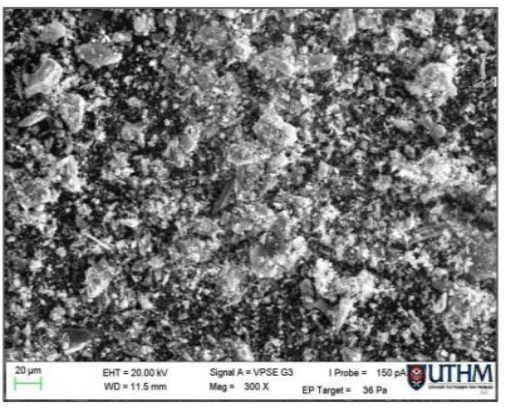

(e) $6 \mathrm{H}-\mathrm{PPA}$

Fig. 3: Microstructural analysis of P. purpureum ashes.

Table 3: The mix composition of mortar cube

\begin{tabular}{cccccc}
\hline Sample & Water-to-cement ratio & $\begin{array}{c}\text { Water } \\
(\mathbf{m l})\end{array}$ & $\begin{array}{c}\text { Cement } \\
(\mathbf{g})\end{array}$ & $\begin{array}{c}\text { PPA } \\
(\mathbf{g})\end{array}$ & $\begin{array}{c}\text { Sand } \\
(\mathbf{g})\end{array}$ \\
\hline Control & & 359 & 740 & - & 2035 \\
$5 \%$ & 0.485 & 359 & 703 & 37 & 2035 \\
$10 \%$ & 0.485 & 359 & 666 & 74 & 2035 \\
$15 \%$ & 0.485 & 359 & 629 & 111 & 2035 \\
\hline
\end{tabular}

\subsubsection{Standard Consistency and Setting Time Tests}

The standard consistency test was applied to the Ordinary Portland Cement and blended cement paste with $5 \%, 10 \%, 15 \%$, and $20 \%$ of replacement by PPA as per ASTM C187 [17]. The Vicat apparatus with a plunger of diameter $10 \mathrm{~mm}$ was used for the test. The amounts of water for normal consistencies of all samples were calculated using Eq. 2.

$$
\text { Normal consistency }(\%)=\frac{M_{W}}{M_{C}} \times 100 \%
$$

where $M_{W}$ is the mass of water $(\mathrm{g})$ and $M_{C}$ is the mass of cement $(\mathrm{g})$.

On the other hand, the setting time test was conducted as per ASTM C191 [18] to determine the value of the Vicat initial and final time of setting of OPC and blended paste with $5 \%, 10 \%, 15 \%$, and $20 \%$ cement replacement with PPA. A paste that was proportioned and mixed to normal consistency, as described in the test method ASTM C187 [17], was molded and placed in a moist cabinet and allowed to start setting. Periodic penetration tests were performed on this paste by the Vicat apparatus with a needle of diameter $1 \mathrm{~mm}$. 
The Vicat initial setting time was the time elapsed between the initial contact of cement and water and the time when the penetration is measured to be $25 \mathrm{~mm}$. The Vicat final setting time was the time elapsed between initial contact of cement-water and the time when the needle does not leave a complete circular impression on the paste surface. The Vicat setting times were calculated to the nearest 1 minute according to Eq. 3 .

$$
\text { Setting time }=\left(\left(\frac{(H-E)}{(C-D)}\right) \times(C-25)\right)+E
$$

\subsubsection{Compressive Testing}

The samples were cast into cubical molds with a size of $50 \mathrm{~mm} \times 50 \mathrm{~mm} \times 50 \mathrm{~mm}$. The top of the sample was smoothened and leveled off with a straight edge trowel. The samples were placed in a moist place immediately upon completion of molding. After 24 hours, the samples were removed from the molds and immersed in the water storage tanks until the testing day. Compressive strength tests were conducted as per ASTM C109 [19] for each replacement percentage and grinding time at the age of 3, 7, and 28 days curing age. The load rate with a range of 900 to $1800 \mathrm{~N} /$ second was applied to the specimen.

\subsubsection{Water Absorption Testing Procedure}

Mortar cube samples of size $50 \mathrm{~mm} \times 50 \mathrm{~mm} \times 50 \mathrm{~mm}$ were cast for water absorption testing. After $24 \pm 1$ hour of curing, the mortar cube samples were cured in a moisture tight plastic bag at $24 \pm 8{ }^{\circ} \mathrm{C}$ until it reaches the age of 3,7 , and 28 days. Then, the mortar cube samples were dried in a ventilated oven at $110 \pm 5{ }^{\circ} \mathrm{C}$ for around 24 hours. The successive weights of the samples were checked at an interval of 2 hours until two successive weights showed an increment of loss not greater than $0.2 \%$. The mortar cube samples were then removed from the oven and were cooled until the samples achieved ambient temperature. Then after 24 hours, the water absorption test was conducted by following the Average Absorption Standard Test Method for Rate of Water Absorption of Mortars ASTM C1403 [20]. The water absorption rate at 24 hours \pm 15 minutes was calculated following Eq. 4, and recorded as " $\mathrm{A}_{\mathrm{T}}$ ". The $\mathrm{A}_{\mathrm{T}}$ (Avg.) was calculated for each set of three cube samples.

$$
\mathrm{AT}=\left(\mathrm{W}_{\mathrm{T}}-\mathrm{W}_{0}\right) \times 10000 /\left(\mathrm{L}_{1} \times \mathrm{L}_{2}\right)
$$

where WT $(\mathrm{g})$ is the weight of cube sample at time $\mathrm{T}, \mathrm{W}_{0}(\mathrm{~g})$ is the initial weight of cube sample, $L_{1}$ is the average length $(\mathrm{mm})$ of test surface of cube sample, and $\mathrm{L}_{2}(\mathrm{~mm})$ is the average width of test surface of cube sample.

The percentage of water absorption $\mathrm{A}_{\mathrm{T}}(\%)$ also was calculated using Eq. 5.

$$
\mathrm{A}_{\mathrm{T}}=\left[\left(\mathrm{W}_{\mathrm{T}}-\mathrm{W}_{0}\right) /\left(\mathrm{W}_{0}\right)\right] \times 100 \%
$$

\section{RESULTS AND DISCUSSION}

\subsection{Loss on Ignition}

The results of loss on ignition (LOI) for all PPA samples were shown in Table 4. Based on the results, the LOI of all PPA samples was below 6\%, ranging from 5.27\% to $5.47 \%$. The lack of significant variations between samples means that the grinding durations do not affect the LOI of PPA. Meanwhile, the LOI for OPC was $2.25 \%$, which was lower than PPA. However, Cordeiro and Sales [9] stated that it is important to emphasize that all ashes presented LOI lower than 5\%, indicating that the burning procedures were appropriate to produce pozzolan from PPA in the context of carbon content. However, LOI lower than 5\% could not be achieved in this study, possibly due to untreated PPA with hydrochloric acid 
pretreatment. However, ASTM C618-3 [21] limits the LOI of pozzolanic materials to less than $6 \%$, largely because higher LOI levels commonly result in discoloration, poor air entrainment, segregation, and low compressive strength of the mixed components. Note that this standard is specified principally for fly ashes. For other calcined natural pozzolans, the ASTM C618-3 [21] limits the LOI at 10\%, since these materials are produced at lower burning temperatures $\left(500{ }^{\circ} \mathrm{C}\right.$ to $\left.800{ }^{\circ} \mathrm{C}\right)$ and contain higher LOI levels.

Table 4. Loss on ignition of PPA

\begin{tabular}{lcccc}
\hline \multicolumn{1}{c}{ Sample } & 1H PPA & 3H & 6H PPA & OPC \\
& & PPA & & \\
\hline Weight of crucible, $\mathrm{W}_{1}(\mathrm{~g})$ & 24.383 & 24.385 & 24.383 & 24.387 \\
Initial Weight of crucible + PPA, $\mathrm{W}_{2}(\mathrm{~g})$ & 25.883 & 25.885 & 26.183 & 25.887 \\
Final Weight of crucible + PPA, $\mathrm{W}_{3}(\mathrm{~g})$ & 25.804 & 25.803 & 26.087 & 25.853 \\
Loss on ignition (\%) & 5.27 & 5.47 & 5.33 & 2.25 \\
\hline
\end{tabular}

Legend: 1H-PPA: 1-hour ground PPA; 3H-PPA: 3-hour ground PPA; 6H-PPA: 6-hour ground PPA.

\subsection{Standard Consistency of Cement Paste Containing PPA}

According to ASTM C191 [18], the standard consistency test is related to the quantity of water that should be able to flow in the fresh mixture. The plasticity of cement capacity to flow will increase if excessive water is added, while the cement will be stiff with a lower quantity of water. Fig. 4 shows the standard consistency results of cement paste containing PPA compared to the OPC paste. From the results, the standard consistency of OPC was $38 \%$. Meanwhile, the standard consistency of cement paste containing PPA increased with the increase of replacement level percentage of PPA.

The standard consistency of the samples with 5\%,10\%, 15\%, and 20\% 1H-PPA were $39 \%, 41 \%, 50 \%$, and 53\%, respectively. For the cement paste containing 5\%, 10\%, 15\%, and $20 \%$ of $3 \mathrm{H}-\mathrm{PPA}$, the standard consistency was $40 \%$, 53\%, and $57 \%$, respectively, which does not differ much from the standard consistency of 1H-PPA. The same pattern applies to cement paste containing $5 \%$ to $20 \%$ of $6 \mathrm{H}-\mathrm{PPA}$ with normal consistency ranges from $42 \%$ to 57\%. All of the above results show that the cement pastes containing PPA have higher standard consistency than OPC due to the properties of PPA that absorbed the water during the early hydration process of cement and PPA mixtures. The standard consistency of cement paste containing PPA also increased with the increase of PPA sizes. As the specific surface area of PPA increased, the water demand would be increased [22]. However, the standard consistency of cement paste containing $15 \%$ and $20 \%$ of $3 \mathrm{H}-\mathrm{PPA}$ was the same as $15 \%$ and $20 \%$ of $6 \mathrm{H}-\mathrm{PPA}$. The increased water demand for the PPA paste to achieve the same level of consistency may be due to the ability of the PPA particles to quickly absorb the mixed water from the paste due to their cellular microstructure. At any constant replacement level and particle size of PPA, the standard consistency of the PPA paste was higher than the control OPC paste. This is because the rate of water absorption of the PPA particles is higher than that of the OPC particles due to the presence of larger pore sizes and wider pore size distribution of the former. Venkatanarayanan and Rangaraju [23] proved that the grinding of PPA may not significantly reduce the absorption of water by its grains and hence, affected the workability characteristics of concrete and mortars. The OPC paste registered lower standard consistency probably due to the lower specific surface area and non-cellular shape of the OPC particles compared to the ground PPA paste. 


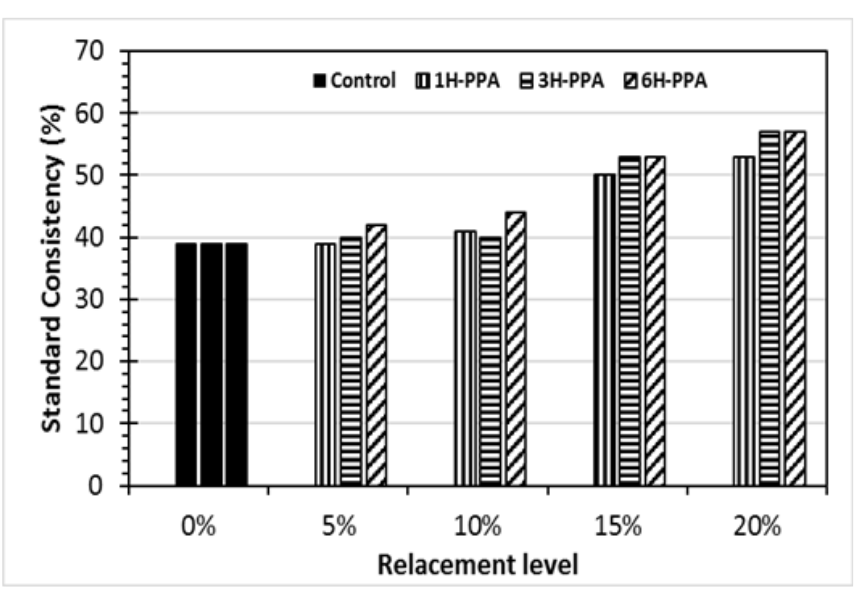

Fig. 4: Standard consistency of cement paste containing PPA at different replacement rate and control paste.

\subsection{Setting Time of Cement Paste Containing PPA}

The results of the setting time of OPC paste and paste containing PPA were shown in Fig. 5. The initial setting time (I-ST) for the samples containing PPA started from 226 minutes for 5\% 1H-PPA to the longest I-ST of 298 minutes for $20 \% 6 \mathrm{H}-\mathrm{PPA}$ while the IST of the cement paste was 269 minutes.

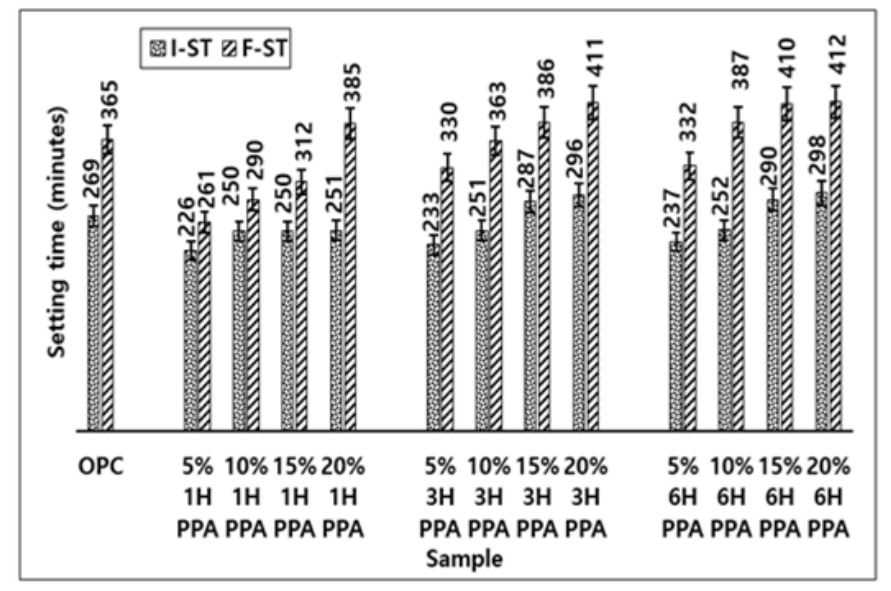

Fig. 5: Setting time of cement paste containing PPA at different replacement rates and control paste.

The final setting time (F-ST) started from 261 minutes for 5\% 1H-PPA to the longest F-ST of 412 minutes for 20\% 6H-PPA while the F-ST of cement paste was 365 minutes. Based on the results, it was found that the mortar containing PPA achieved lower I-ST and F-ST than the control mortar except for those containing 15\% and 20\% PPA. However, both I-ST and F-ST increased with the increase of cement replacement percentage with PPA. Also, both I-ST and F-ST slightly increased with the increase of grinding time in which $3 \mathrm{H}-$ PPA and 6H-PPA have longer initial and final setting times than 1H-PPA pastes. The setting time behavior is a function of the rate of stiffening of the paste influenced by the effective water to cement ratio [23]. The effective water to cement ratio is the remaining water available to react with Portland cement after the water was absorbed by the pozzolan grains. At any percentage of replacement of PPA, the lower grinding time of PPA was shown to absorb more water due to greater porosity resulting in lower effective water to cement ratio in pastes. Thus, the final setting time would be shorter for the specimens containing larger 
particle sizes of PPA due to the reduction of porosity with continued hydration, hence affecting their stiffening rate of the paste.

\subsection{Water Absorption Rate of Mortar Containing PPA}

The effects of PPA replacement with cement at different percentages and particle sizes on the water absorption rate of cement mortar mixes are shown in Fig. 6. The results show that all samples containing PPA initially exhibited a high-water absorption rate for 3 days. The water absorption rate significantly slowed down for 7 days and 28 days as most of the pores available had become saturated. It is found that the absorption rate of the mortar containing PPA was higher than the control samples at all testing ages and replacement levels. However, $15 \%$ 6H-PPA samples at 7 days and 28 days displayed a lower water absorption rate than the control sample. It was observed that the water absorption rate increased as the replacement level of 1H-PPA and 3H-PPA increase, while it remains unchanged for $6 \mathrm{H}-\mathrm{PPA}$.

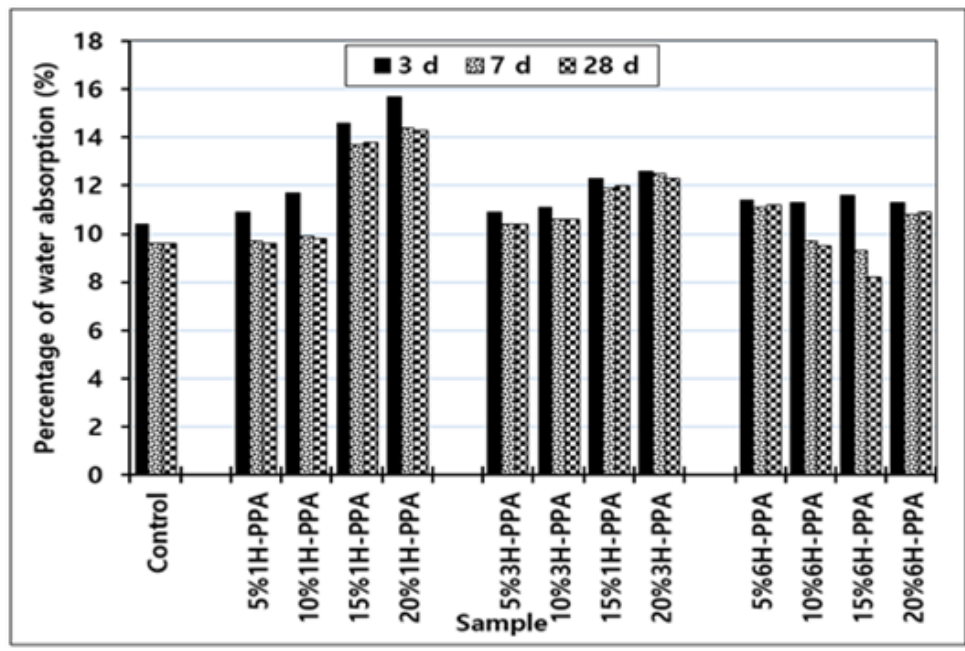

Fig. 6: Percentage of water absorption of 1H-PPA mortar after 24 hours of immersion.

Based on Fig. 6, the finer samples (3H-PPA and 6Hh-PPA) exhibited a lower water absorption rate than 1H-PPA samples. This is due to the filler effect, in which the voids between the cement grains are filled with a micro size of silica particles available in pozzolan to enhance its structural properties. A higher packing density resulted in lower water demand of the mixture with the right composition of pozzolans, which also contributed to the strength enhancement due to the reduced capillary porosity [24]. The higher the percentage of PPA replacement, the denser the particle packing in cement mortar, which also applies to the fineness of PPA. Also, the incorporation of suitable fine pozzolan refined the pore structure and reduces the porosity of cement-based materials due to filler and nucleation effects [25].

\subsection{Compressive Strength with Activity Index of Mortar Containing PPA}

The results of the compressive strength of cement mortar containing PPA for all percentages based on grinding durations at the testing age of 3 days, 7 days, and 28 days were illustrated in Fig. 7. Based on the plot, the strength of mortar increased linearly with the curing ages for all samples.

The results also displayed that the compressive strength of the mortar sample increased with the increase of cement replacement of up to $15 \%$ with PPA in the mortar mix, but then the strength mostly decreased after $15 \%$ of PPA replacement. However, the strength 
obtained was still higher than the control mortar. The filler supplemented the dense-pack structure in cement mortar and the filler dispersed very well. Filler effect or particle size effect is defined as the proper arrangement of small particles that fill the voids and contribute to the increment of compressive strength without any chemical reaction [26]. The compressive strength of cement mortar may be increased due to pore refinement from the pozzolanic reaction of PPA with the cement particles. Furthermore, finer PPA could react more quickly with $\mathrm{Ca}(\mathrm{OH})_{2}$ and increase the compressive strength of mortar due to the pozzolanic reaction.

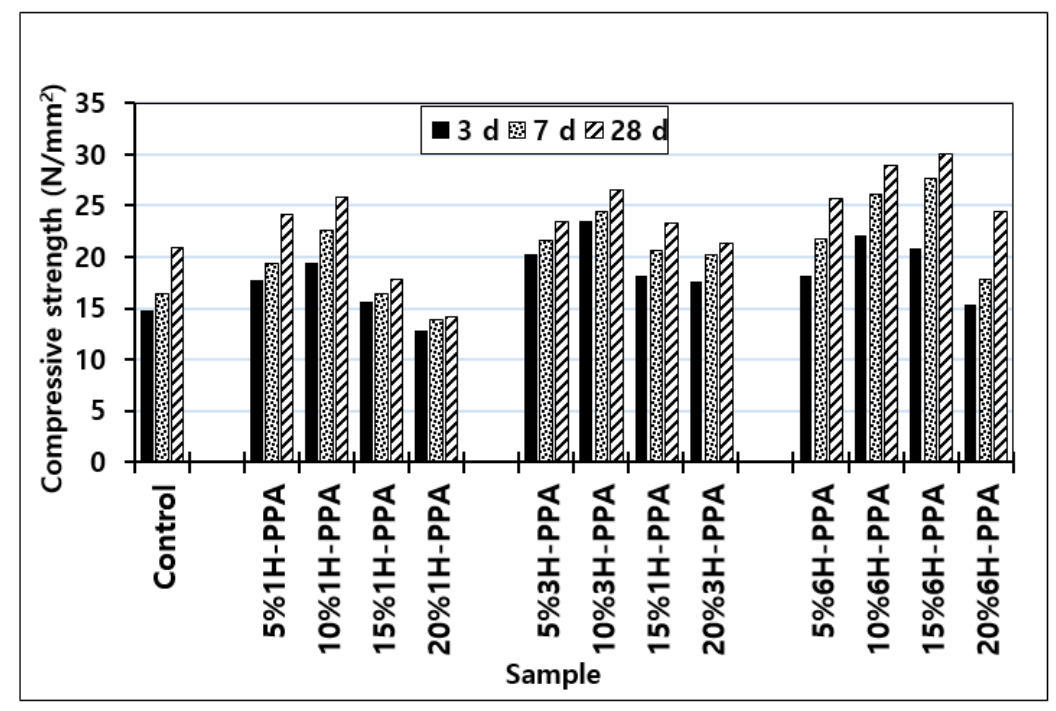

Fig. 7: Compressive strength of mortar containing PPA at 3 days, 7 days, and 28 days.

Overall, the compressive strength of cement mortar decreases with increased PPA dosage starting from $10 \%$ of replacement. It is observed that the optimum compressive strength is approximately $10 \%$ of PPA replacement. However, the mortar containing $15 \%$ of $6 \mathrm{H}-\mathrm{PPA}$ at 28 days has the highest strength among all samples in which it achieved a strength of $30 \mathrm{MPa}$. In the context of grinding time, the 3 hours grinding time achieved the highest compressive strength at 3 days followed by 6 hours, and 1 hour, respectively. However, the compressive strength at 7 days and 28 days increased with the increase of the grinding time of the PPA in which the 6-hours grinding time achieved the highest compressive strength followed by 3 hours and 1 hour, respectively. Therefore, the 6-hours grinding was found to be the optimum grinding time for the PPA as a replacement of cement for the mortar.

The compressive strength activity indices for all mortars containing PPA are listed in Table 5. At each testing time, the strength index is defined as the ratio of the compressive strength of the mortar containing PPA to the strength of the control sample. It is mostly depending on the hydration rate. The minimum requirement of $75 \%$ of the strength activity index was achieved by mortar containing ash as specified in ASTM C618 [21]. Based on Table 5, all strength activity indices at the ages of 3 days, 7 days, and 28 days were higher than the minimum requirement of 75\% as stated in ASTM C618 [21]. It was found that the strength activity index decreased compared to the control sample due to replacing $10 \%$, $15 \%$, and $20 \% 1 \mathrm{H}-\mathrm{PPA}$ at the age of 28 days, as well as $20 \% 1 \mathrm{H}-\mathrm{PPA}$ at the ages of 3 days and 7 days. This is due to the mitigation influence and delay of the pozzolanic reaction of $\mathrm{PPA} / \mathrm{Ca}(\mathrm{OH})_{2}$. Altwair et al. [27] found the same result for a $20 \%$ replacement of OPC with POFA at the age of 3 and 7 days. However, the samples with a high fineness (3H-PPA and 
6H-PPA) achieved strength indices higher than the control samples for all replacement percentages. This is due to the amorphous aluminous and siliceous minerals that still actively react with $\mathrm{Ca}(\mathrm{OH})_{2}$, producing $\mathrm{C}-\mathrm{S}-\mathrm{H}$ and hydrated calcium aluminates, improving interfacial bonding between the sand and pastes. The outcome of this study is in agreement with Altwair et al. [27] in which the POFA cement mortar recorded a strength activity index of $101.72 \%$.

Table 5: Strength activity index (\%)

\begin{tabular}{cccc}
\hline Sample & \multicolumn{3}{c}{ Testing age (days) } \\
\cline { 2 - 4 } & $\mathbf{3}$ & $\mathbf{7}$ & $\mathbf{2 8}$ \\
\hline Control & 100 & 100 & 100 \\
$5 \% 1 \mathrm{H}-\mathrm{PPA}$ & 120 & 119 & 115 \\
$10 \% 1 \mathrm{H}-\mathrm{PPA}$ & 131 & 138 & 81 \\
$15 \% 1 \mathrm{H}-\mathrm{PPA}$ & 106 & 100 & 76 \\
$20 \% 1 \mathrm{H}-\mathrm{PPA}$ & 87 & 84 & 78 \\
\hline $5 \% 3 \mathrm{H}-\mathrm{PPA}$ & 150 & 132 & 91 \\
$10 \% 3 \mathrm{H}-\mathrm{PPA}$ & 159 & 149 & 127 \\
$15 \% 3 \mathrm{H}-\mathrm{PPA}$ & 123 & 127 & 112 \\
$20 \% 3 \mathrm{H}-\mathrm{PPA}$ & 118 & 124 & 97 \\
\hline $5 \% 6 \mathrm{H}-\mathrm{PPA}$ & 123 & 133 & 123 \\
$10 \% 6 \mathrm{H}-\mathrm{PPA}$ & 149 & 160 & 138 \\
$15 \% 6 \mathrm{H}-\mathrm{PPA}$ & 141 & 169 & 144 \\
$20 \% 6 \mathrm{H}-\mathrm{PPA}$ & 104 & 108 & 117 \\
\hline
\end{tabular}

Furthermore, the impact of replacing cement with PPA in the mortar was examined using the microstructure images analysis through SEM at 28 days as shown in Fig. 8. The microstructure of mortar containing 15\% of PPA has hydrated products consisting of ettringite and C-S-H particle as shown in Fig. 8d. Ettringite formed in needle-like or club shape crystal, while C-S-H was in fine layer particle, both found in a mortar containing $15 \%$ PPA at 28 days curing period but did not exist in the control mortar. This is illustrated the highest strength for 28 days curing period of $15 \%$ of PPA.

\section{CONCLUSION}

Based on the results, the following conclusions can be drawn:

- The characterization of PPA material based on chemical composition, particle size distribution, and X-ray diffraction showed that the PPA material is adequate to produce pozzolan; however, it did not achieve $50 \%$ and $70 \%$ of reactive oxides to be classified as Class $\mathrm{F}$ or Class $\mathrm{C}$ pozzolan, respectively. Therefore, the PPA is more suitable as filling material than the pozzolanic material as a substitute for OPC, which helps in reducing the environmental pollution during the disposal of excess elephant grass wastes. Although the particle shape of the ground PPA had better dispersion than UG-PPA, the grinding durations do not affect the chemical composition and LOI of PPA. 


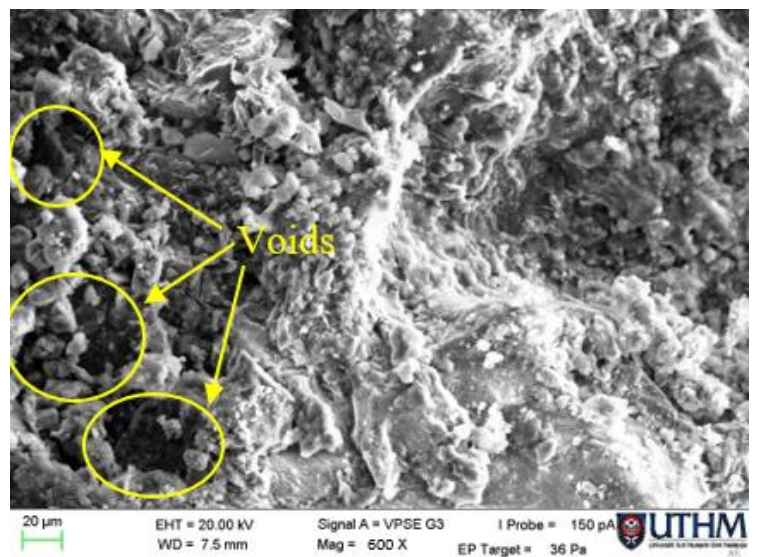

(a) Control

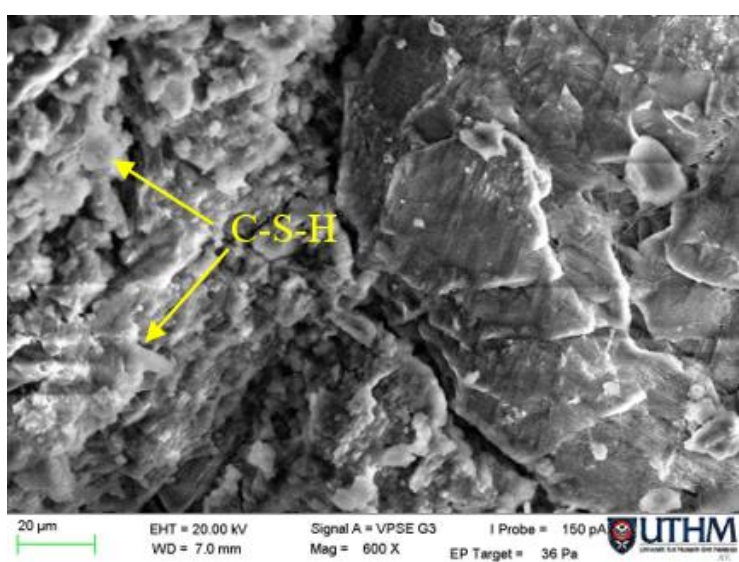

(b) $5 \%$ PPA

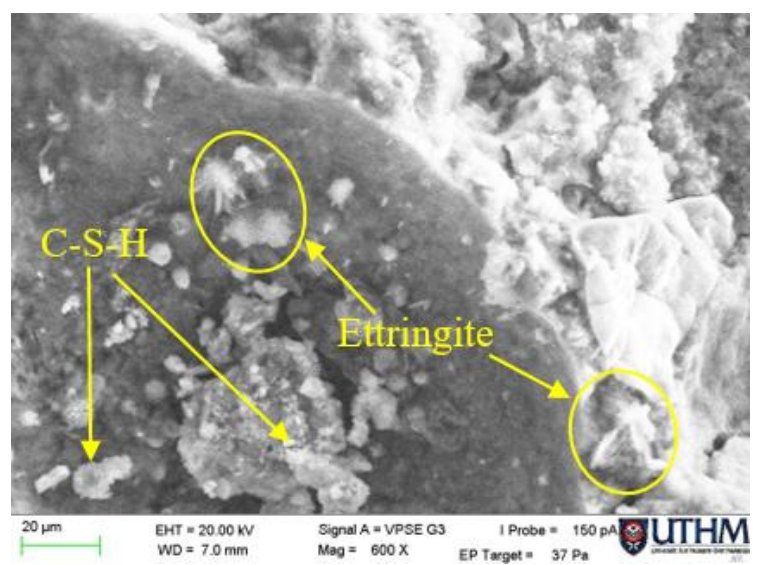

(d) $15 \%$ PPA

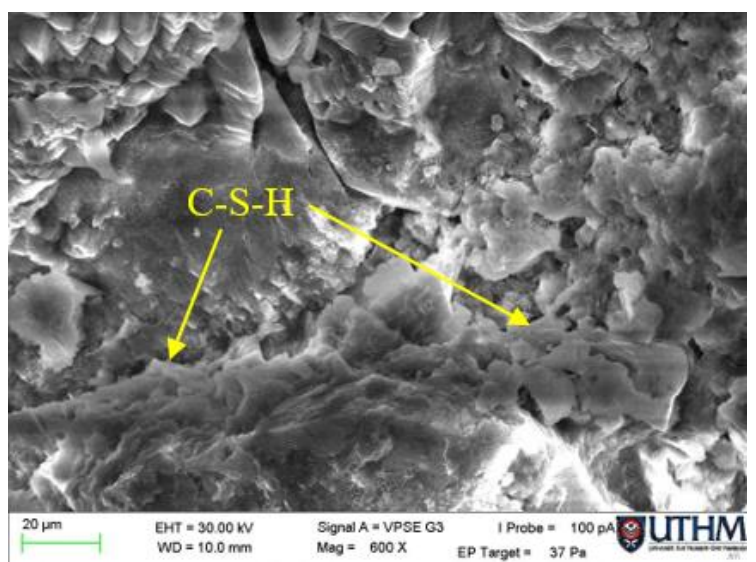

(c) $10 \%$ PPA

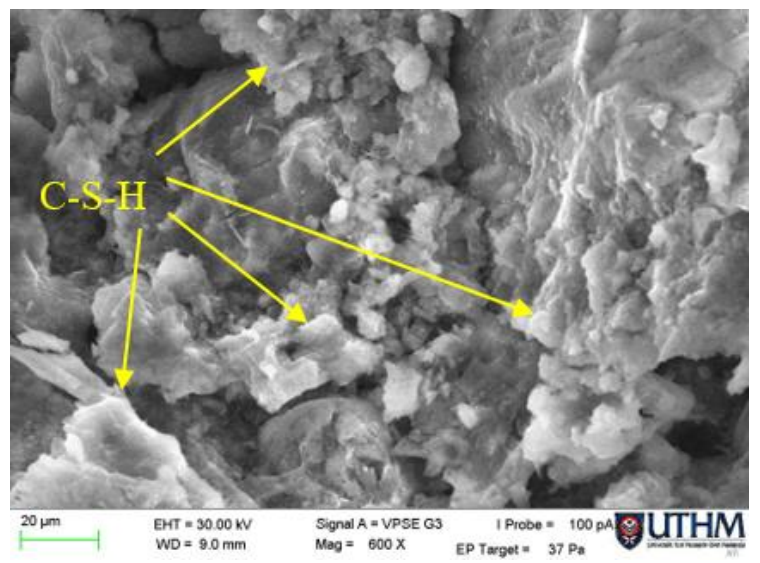

(e) $20 \%$ PPA

Fig. 8: Scanning Electron Micrographs of mortar mixtures at 28 days.

- The mortar containing PPA achieved a higher standard consistency value than the control sample while it gained a lower setting time except for those containing $15 \%$ and $20 \%$ PPA. However, the standard consistency and setting time of cement paste containing PPA increased with the increase of PPA grinding time.

- The compressive strength of cement mortar increased with the increase of PPA until $10 \%$ for all grinding times, then it was decreased with the increase of PPA percentage.

- The mortar containing PPA achieved a water absorption rate higher than the control samples at all testing ages and replacement levels. The water absorption rate 
increased as the replacement level of 1H-PPA and 3H-PPA increased, while it remained unchanged for $6 \mathrm{H}-\mathrm{PPA}$.

- The 6-hours grinding was found to be the optimum grinding time for the PPA as a replacement of cement for the mortar as it achieved the highest compressive strength at 7 and 28 days.

- The $15 \%$ of $6 \mathrm{H}-\mathrm{PPA}$ at 28 days was found to be the optimum PPA replacement dosage and grinding time with cement as it achieved the highest strength and lower water absorption rate among all samples at 7 and 28 days.

- Finally, based on the results of chemical analysis and strength activity index, the characterization displayed the potential pozzolan of PPA, although it is not Class F or Class C pozzolan. Therefore, the PPA can be considered as filler and source of pozzolan production in tropical regions.

\section{ACKNOWLEDGEMENT}

The research described in this paper was financially supported by Research Management Centre (RMC), Universiti Tun Hussein Onn Malaysia (UTHM), under grant GPPS Vot No. U45.

\section{REFERENCES}

[1] Ghiasvand E, Ramezanianpour A. (2017) Effect of grinding method and particle size distribution on long term properties of binary and ternary cements. Construction and Building Materials, 134: 75-82. https://doi.org/10.1016/j.conbuildmat.2016.12.122

[2] Cordeiro GC, Kurtis KE. (2017) Effect of mechanical processing on sugar cane bagasse ash pozzolanicity. Cement and Concrete Research, 97: 41-49. https://doi.org/10.1016/j.cemconres.2017.03.008

[3] Ambedkar B, Alex J, Dhanalakshmi J. (2017) Enhancement of mechanical properties and durability of the cement concrete by RHA as cement replacement: Experiments and modeling. Construction and Building 167-175. https://doi.org/10.1016/j.conbuildmat.2017.05.022

[4] Thomas BS, Kumar S, Arel HS. (2017) Sustainable concrete containing palm oil fuel ash as a supplementary cementitious material-A review. Renewable and Sustainable Energy Reviews, 80: 550-561. https://doi.org/10.1016/j.rser.2017.05.128

[5] Adesanya DA, Raheem AA. (2009) Development of corn cob ash blended cement. $\begin{array}{llll}\text { Construction } \text { and } & \text { 347-352. }\end{array}$ https://doi.org/10.1016/j.conbuildmat.2007.11.013

[6] Mohammed I, Abakr Y, Kabir F, Yusup S. (2015) Effect of aqueous pretreatment on pyrolysis characteristics of napier grass. Journal of Engineering Science and Technology, 10(11): 14871496. http://jestec.taylors.edu.my/Vol\%2010\%20Issue\%2011

[7] Ghani WWAK, Salleh MAM, Adam SN, Shafri HM, Shaharum SN, Lim KL, Tapia JF. (2019) Sustainable bio-economy that delivers the environment-food-energy-water nexus objectives: the current status in Malaysia. Food and Bioproducts Processing, 118: 167-186. https://doi.org/10.1016/j.fbp.2019.09.002

[8] Cordeiro GC, Sales CP. (2015) Pozzolanic activity of elephant grass ash and its influence on the mechanical properties of concrete. Cement and Concrete Composites, 55: 331-336. https://doi.org/10.1016/j.cemconcomp.2014.09.019

[9] Saruchera L, Mupa M, Muchanyereyi-Mukuratirwa N, Witzleben S. (2018) A study on the pozzolanic properties of Pennisetum Purpureum ash. Journal of Interdisciplinary Academic Research, 1: 1-10. https://doi.org/10.32476/b9691748-2ac0-4d2fab85-6660b03aeac5 
[10] Nakanishi EY, Frías M, Martínez-Ramírez S, Santos SF, Rodrigues MS, Rodríguez O, Savastano Jr H. (2014) Characterization and properties of elephant grass ashes as supplementary cementing material in pozzolan $/ \mathrm{Ca}(\mathrm{OH})_{2}$ pastes. Construction and Building Materials, 73: 391-398. https://doi.org/10.1016/j.conbuildmat.2014.09.078

[11] Cordeiro GC, Sales CP. (2016) Influence of calcining temperature on the pozzolanic characteristics of elephant grass ash. Cement and Concrete Composites, 73: 98-104. https://doi.org/10.1016/j.cemconcomp.2016.07.008

[12] Nakanishi EY, Frías M, Santos SF, Rodrigues MS, de la Villa RV, Rodriguez O, Junior HS. (2016) Investigating the possible usage of elephant grass ash to manufacture the eco-friendly binary cements. Journal of Cleaner Production, 116: 236-243. https://doi.org/10.1016/j.jclepro.2015.12.113

[13] Ramadhansyah PJ, Bakar BA, Azmi MM, Ibrahim MW. (2011) Engineering properties of normal concrete grade 40 containing Rice husk ash at different grinding times. International Journal of Technology, 2(1): 10-19.

[14] EN 197-1 (2000) Cement: Part 1. Compositions and conformity criteria for common cements.

[15] Abu Bakar BH, Ramadhansyah PJ, Megat Azmi MJ. (2011) Effect of rice husk ash fineness on the chemical and physical properties of concrete. Magazine of Concrete Research, 63(5): 313-320. https://doi.org/10.1680/macr.10.00019

[16] ASTM C114 (2007) Standard Test Methods for Chemical Analysis of Hydraulic Cement. ASTM International. West Conshohocken, PA.

[17] ASTM Designation C187-04 (2004) Standard test method for normal consistency of hydraulic cement. West Conshohocken, PA.

[18] ASTM C191-08 (2008) Standard Test Method for Time of Setting of Hydraulic Cement by Vicat Needle, West Conshohocken, PA, USA.

[19] ASTM C109-08 (2008) Standard test method for compressive strength of hydraulic cement mortars. ASTM International, West Conshohocken, PA.

[20] ASTM C1403-14 (2014) Standard Test Method for Rate of Water Absorption of Masonry Mortars, ASTM International, West Conshohocken, PA.

[21] ASTM C618 (2008) Standard specification for coal fly ash and raw or calcined natural pozzolan for use as a mineral admixture in concrete Cement; Lime; Gypsum, Annual Book of ASTM Standards, vol. 04.01, American Society for Testing and Materials, Philadelphia, PA.

[22] Sathawane SH, Vairagade VS, Kene KS. (2013) Combine effect of rice husk ash and fly ash on concrete by 30\% cement replacement. Procedia Engineering, 51: 35-44. https://doi.org/10.1016/j.proeng.2013.01.009

[23] Venkatanarayanan HK, Rangaraju PR. (2015) Effect of grinding of low-carbon rice husk ash on the microstructure and performance properties of blended cement concrete. Cement and concrete composites, 55: 348-363. https://doi.org/10.1016/j.cemconcomp.2014.09.021

[24] Rai S, Tiwari S. (2018) Nano silica in cement hydration. Materials Today: Proceedings, India, 5(3): 9196-9202. https://doi.org/10.1016/j.matpr.2017.10.044

[25] Wang D, Shi C, Farzadnia N, Shi Z, Jia H, Ou Z. (2018) A review on use of limestone powder in cement-based materials: Mechanism, hydration and microstructures. Construction and Building Materials, 181: 659-672. https://doi.org/10.1016/j.conbuildmat.2018.06.075

[26] Jaturapitakkul C, Tangpagasit J, Songmue S, Kiattikomol K. (2011) Filler effect and pozzolanic reaction of ground palm oil fuel ash. Construction and Building Materials, 25(11): 4287-4293. https://doi.org/10.1016/j.conbuildmat.2011.04.073

[27] Altwair NM, Johari MAM, Hashim SFS. (2011) Strength activity index and microstructural characteristics of treated palm oil fuel ash. International Journal of Civil \& Environmental Engineering, 11: 100-107 